\title{
自己抗体と同種抗体を保有する患者への赤血球輸血： 主要な同種抗原を適合させた赤血球の選択と輸血効果の検討
}

\begin{tabular}{|c|c|c|c|c|c|c|c|c|}
\hline 安田 & 広康 ${ }^{1)}$ & 奥津 & 美穂 ${ }^{1)}$ & 川畑 & 絹代 ${ }^{11}$ & 三浦 & 里織1) & 馬場千華子 ${ }^{11}$ \\
\hline 小旦 & 智1) & 郡司 & 陽子 ${ }^{1)}$ & 渡部 & 和也 ${ }^{1)}$ & 小幡 & 悠子 ${ }^{1)}$ & 菊池 良子 ${ }^{2)}$ \\
\hline
\end{tabular}

自己抗体は，不規則抗体検查においてすべてのパネル血球と反応し，しばしば臨床的に重要な同種抗体の存在を 隱蔽する．同種抗体を検出するため, ZZAP や PEG (polyethylene glycol) 吸着法を用いて患者血清中の自己抗体を 除去した。 また，輸血効果と溶血性副作用の有無の評価には，それぞれ輸血前後のへモグロビン上昇率（\% $\mathrm{Hb})$ と $\mathrm{LDH}$ 值の変動率を用いた.

自己抗体を保有した 5 名の非 AIHA（autoimmune hemolytic anemia）患者で，自己抗体を吸着除去した上清中に 抗 $\mathrm{Di}^{\mathrm{a}}$ ，抗 $\mathrm{E}$ ，抗 $\mathrm{c}+\mathrm{E}$ ，抗 $\mathrm{c}+\mathrm{E}+\mathrm{Jk}^{\mathrm{b}}+\mathrm{Di}^{\mathrm{i}}$ ，抗 $\mathrm{C}+\mathrm{e}$ をそれぞれ検出した。 これらの患者へは同種抗体に対する抗原 陰性の赤血球を輸血した．対応抗原陰性血を輸血した自己抗体保有群の％Hb は平均 $89 \%$ で，コントロール群（平 均 84\%) との差は無かった。また, 輸血後の LDH 值にも有意な変動はなく, 両群間の比較でも差を認めなかった.

自己抗体を保有する患者においては，同種抗体の検出には自己抗体吸着法が有用であったままた，自己抗体と同 種抗体をもつ非 AIHA 患者への輸血には，主要な同種抗原を適合させた赤血球が効果的であった.

キーワード：自己抗体，同種抗体，吸着試験，ZZAP，PEG

\section{はじめに}

温式自己抗体（以下自己抗体）には，赤血球の寿命 を著しく短縮し自己免疫性溶血性貧血(AIHA：autoimmune hemolytic anemia)の原因となるものから，体内 で赤血球と結合しても溶血を起こさないものまで様々 である ${ }^{1)}$.しかし，日常検査に执いてしばしば遭遇する 自己抗体は，直接抗グロブリン試験 (DAT： direct antiglobulin test）が陽性であっても非溶血性のものが多 ( ${ }^{2}$. 従って, 自己抗体を有する非 AIHA 患者において は，輸血後の溶血性副作用を回避するため，共存する 同種抗体に留意しなければならない.

自己抗体は，間接抗グロブリン試験 (IAT：indirect antiglobulin test）においてすべてのパネル血球と反応 し，同種抗体の存在を隠蔽することが多い，共存する 同種抗体を検出するためには，通常 3 カ月以内に輸血 歴が無ければ患者血球を用いて自己抗体吸着法が実施 できる ${ }^{3)}$. 自己抗体吸着法には ZZAP 吸着法) と PEG （polyethylene glycol）吸着法 ${ }^{56)}$ がある。ZZAP 吸着法 は，患者血球に結合している $\operatorname{IgG}$ 自己抗体をあらかじ め ZZAP 試薬で処理して解離した後, 処理血球を用い
て血清（血漿）中の自己抗体を吸着除去する方法であ る. 一方, PEG 吸着法は PEG の脱水作用による濃縮効 果を利用して抗原抗体反応を高め, 患者血球から IgG 自己抗体を解離することなく患者血清（血漿）中の自 己抗体を吸着除去する方法である. PEG 吸着法は, ZZAP 吸着法よりも操作が簡便で，所要時間も短縮できるこ とから, 海外では ZZAP 吸着法とともに自己抗体吸着 法として用いられている7゙.

造血機能の低下や出血のため赤血球輸血を必要とし た非 AIHA の 5 例の患者に，自己血球を含むすべての パネル血球に反応する自己抗体が検出された。自己抗 体吸着法によって同種抗体を同定し，同種抗体に対す る抗原陰性赤血球を輸血し，輸血効果と溶血の有無に ついて調査した。

\section{対象}

自己抗体と同種抗体を保有し同種血輸血を要した 5 名の患者を対象とした。症例 1 は 30 歳代女性, SLE (systemic lupus erythematosus)，4 年前, 帝王切開術 施行時に輸血を受けた。 症例 2 は 40 歳代女性, 急性リ

\footnotetext{
1）福島県立医科大学附属病院 輸血 - 移植免疫部

2) 白河厚生総合病院 検査科

〔受付日：2007 年 2 月 8 日, 受理日：2007 年 6 月 19 日〕
} 
ンパ球性白血病，輸血歴はなく, 過去 3 回の妊娠歷が ある. 症例 3 は 70 歳代男性, 胃癌, 3 年前, 股関節人 工骨頭置換術施行時に輸血を受けた. 症例 4 は 40 歳代 男性, 出血性腸炎, 5 力月前, 消化管出血時に濃厚赤血 球 12 単位（6ドナー）の輸血を受けた。症例 5 は 60 歳代男性, 心臟弁膜症, 4 力月前, 心臓手術施行時に濃 厚赤血球 7 単位（4 ドナー）の輸血を受けた。

また, 輸血効果や溶血の有無を自己抗体保有群と比 較するため, 出血（点状出血や紫斑を除く）を認めな かった血液疾患患者 15 名をコントロール群とした

\section{方 法}

\section{1. 不規則抗体検査と DAT}

1）不規則抗体検查：IAT は，患者血清（血漿）2 滴に重合ウシアルブミン液（オーソ・クリニカルダイ アグノスティクス KK)または $20 \% \mathrm{PEG}$ (Sigma，MW3, 350 ：自家製）を各 2 滴，スクリーニング血球 (サージ スクリーン ${ }^{\circledR}$ とディエゴ A 血球, オーソ) 1 滴を加え, $37^{\circ} \mathrm{C}$ で 15 分インキュベートし, 洗浄 3 回（PEGでは 4 回), 広範囲抗グロブリン血清(ガンマ クローン IgG, C3d，カイノス）または抗ヒト IgG 血清(ウサギ)（オー ソ）をそれぞれ 2 滴ずつ添加し, 遠心後, 判定した.

2）DAT：患者血球浮遊液 (3〜 5\%) を 4 本の試験管 に 1 滴ずつ加え, 3 回洗浄後, 各試験管には広範囲抗グ ロブリン血清(カイノス), 抗 IgG 血清(ガンマ クロー ン IgG, カイノス), 抗補体血清(ガンマ クローン C3d, カイノス), 生食水を各 2 滴ずつ加え, 遠心後, 判定し た.

\section{2. 患者血球による自己抗体の吸着除去（Table 1）}

1）ZZAP 吸着法：患者血球に吸着した自己抗体は, ZZAP 試薬処理して患者血球から解離した. ZZAP 処理 血球 1 容に患者血清（血漿） 1 容を加え， $37^{\circ} \mathrm{C}$ で 30 分インキュベートして自己抗体を吸着した. 遠心後, 上清を分離した。

2) PEG 吸着法: 未処理患者血球, 患者血清 (血漿), $\mathrm{PEG}$ 試薬（ガンマ $\mathrm{PeG}^{\mathrm{TM}}$ ，カイノス）を各 1 容ずつ加 えて, $37^{\circ} \mathrm{C}$ で 15 分インキュベートして自己抗体を吸着 した，遠心後，上清を分離した。

\section{3. 吸着上清中の赤血球同種抗体検查}

不規則抗体検査には, 両吸着法で得た上清を用いた。 ZZAP 吸着上清中の同種抗体は, 上清 2 滴に重合ウシア ルブミン液または $20 \% \mathrm{PEG}$ を各 2 滴, 各種パネル血球 (リゾルブ囚パネル A とパネル B, オーソ ; パノセル-16, カイノス） 1 滴加え, IATによって検出した. PEG 吸着上清には既に患者血清と等量の PEG 試薬が添加さ れているため，その上清の同種抗体の検出には上清 4 滴に各種パネル血球 1 滴を加え, 同様に IAT によって 検出した。また，交差適合試験では ZZAP またはPEG
Table 1 Autologous adsorption procedures

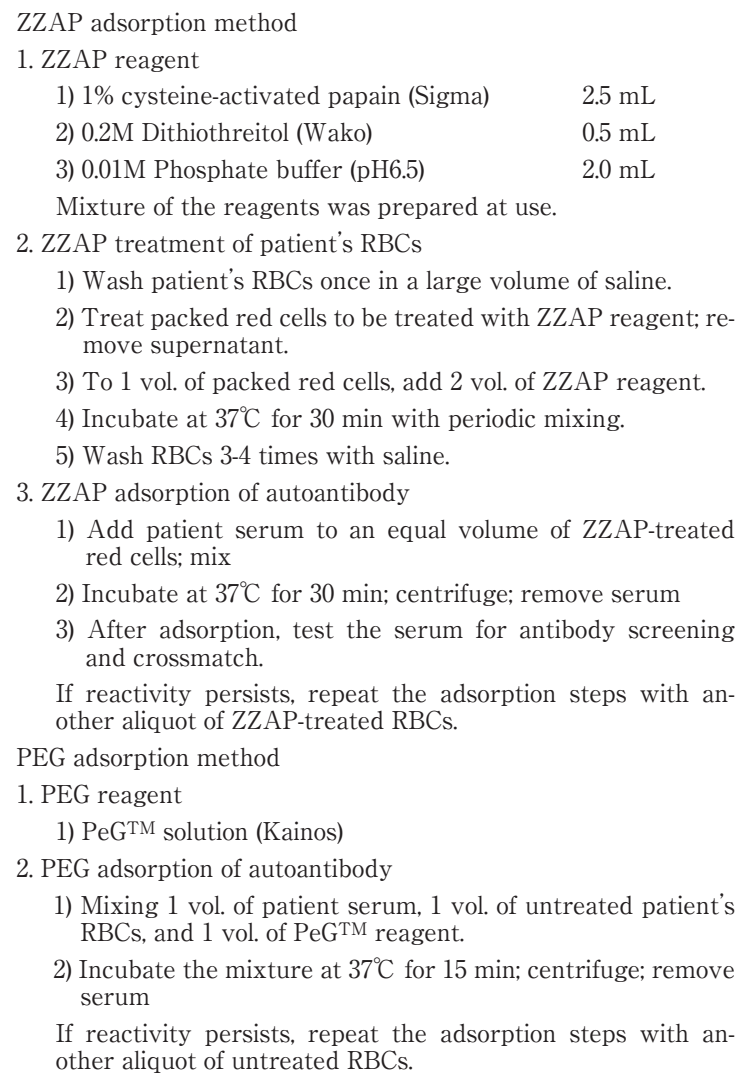
and crossmatch.

If reactivity persists, repeat the adsorption steps with another aliquot of ZZAP-treated RBCs.

PEG adsorption method

1. PEG reagent

1) $\mathrm{PeG}^{\mathrm{TM}}$ solution (Kainos)

2. PEG adsorption of autoantibody

1) Mixing 1 vol. of patient serum, 1 vol. of untreated patient's RBCs, and 1 vol. of PeGTM reagent.

2) Incubate the mixture at $37^{\circ} \mathrm{C}$ for $15 \mathrm{~min}$; centrifuge; remove serum

If reactivity persists, repeat the adsorption steps with another aliquot of untreated RBCs.

吸着上清をそれぞれ 2 滴または 4 滴に，ドナー血球浮 遊液（3〜 5\%）を 1 滴加えて，同様にIATによって実 施した. なお, PEG-IAT の抗グロブリン血清には抗 IgG 血清（オーソ）を用いた.

輸血日から 3 日目以降，さらに輸血が必要となった 場合には，新たに患者検体を入手した，自己抗体が患 者血清（血漿）中に残存していたため, あらかじめ保 管した輸血前患者血球で自己抗体を吸着除去後, 不規 則抗体検査掞よび交差適合試験を実施した。

\section{4. 患者自己抗体吸着用血球の保存}

複数回の輸血が必要な患者(ただし, 3 カ月以内の輸 血歴無し）では, 初回以降の輸血前検查のため自己抗 体吸着用として患者血球を保管した，初回赤血球輸血 直前に患者血を $10 \sim 20 \mathrm{~m} l$ 採血し, 患者血球を無菌的に 分離, 洗浄後, 滤過滅菌したアルセバー溶液に浮遊し, $4^{\circ} \mathrm{C}$ で保存した。

\section{5. 輸血効果と溶血の有無の評価}

自己抗体保有群には, 各患者から検出された同種抗 体に対する抗原陰性濃厚赤血球を 2 単位ずつ, 症例 1 , $3 ， 4 ， 5$ には 2 回，症例 2 には 4 回輸血した（Table 2).

輸血効果は，予測上昇へモグロビン（Hb）值に対す る輸血後の実測上昇 $\mathrm{Hb}$ 值(翌日または翌々日)の割合, 
Table 2 Clinical and laboratory findings of five patients transfused with antigen-negative RBCs corresponding to alloantibodies detected with autoantibody.

\begin{tabular}{|c|c|c|c|c|c|}
\hline & Case 1 & Case 2 & Case 3 & Case 4 & Case 5 \\
\hline Age & $30 \mathrm{~s}$ & $40 \mathrm{~s}$ & $70 \mathrm{~s}$ & $40 \mathrm{~s}$ & $60 \mathrm{~s}$ \\
\hline Gender & $\mathrm{F}$ & $\mathrm{F}$ & M & M & M \\
\hline History of Transfusion/Pregnancy & $+/+$ & $-/+$ & + & + & + \\
\hline Diagnosis & SLE & ALL & $\begin{array}{l}\text { Gastric } \\
\text { cancer }\end{array}$ & Hemorrhagic enteritis & $\begin{array}{l}\text { Valvular } \\
\text { disease } \\
\text { of heart }\end{array}$ \\
\hline $\mathrm{ABO} \& \mathrm{RhD}$ & $\mathrm{O}, \mathrm{D}+$ & $\mathrm{AB}, \mathrm{D}+$ & $\mathrm{O}, \mathrm{D}+$ & $\mathrm{B}, \mathrm{D}+$ & $\mathrm{B}, \mathrm{D}+$ \\
\hline Other blood groups & $\mathrm{Di}^{\mathrm{a}-}$ & $\mathrm{C}+\mathrm{c}+\mathrm{E}-\mathrm{e}+$ & $\mathrm{C}+\mathrm{c}-\mathrm{E}-\mathrm{e}+$ & $\begin{array}{c}\mathrm{C}+\mathrm{c}-\mathrm{E}-\mathrm{e}+, \mathrm{Jk}^{\mathrm{a}+\mathrm{b}-}, \mathrm{Fy}^{\mathrm{a}+\mathrm{b}-} \\
\mathrm{Di}^{\mathrm{a}-}, \mathrm{K}-\mathrm{k}+, \mathrm{Kp}^{\mathrm{a}-\mathrm{b}+}, \mathrm{Js}^{\mathrm{a}-\mathrm{b}+} \\
\text { MNss, } \mathrm{Le}^{\mathrm{a}-\mathrm{b}-}\end{array}$ & $\mathrm{C}-\mathrm{c}+\mathrm{E}+\mathrm{e}-$ \\
\hline Methods of IAT for antibody screening & Alb-IAT & Alb-IAT & PEG-IAT & PEG-IAT & PEG-IAT \\
\hline Results of IAT & $1+\sim 2+$ & $1+\sim 4+$ & $1+\sim 4+$ & $1+\sim 4+$ & $2+\sim 3+$ \\
\hline Results of DAT, anti-IgG & $3+$ & $1+$ & $1+$ & $1+$ & $2+$ \\
\hline Methods of autoantibody adsorption & ZZAP & ZZAP & ZZAP & PEG & PEG \\
\hline Number of adsorption procedures & 1 & 1 & 1 & 1 & 1 \\
\hline $\begin{array}{l}\text { Specificity of alloantibodies detected } \\
\text { in auto-adsorbed sera }\end{array}$ & Anti-Dia & Anti-E & Anti-c, -E & Anti-c, $-\mathrm{E},-\mathrm{Jk}^{\mathrm{b}},-\mathrm{Di}^{\mathrm{a}}$ & Anti-C, -e \\
\hline Alloantibody masked completely by autoantibody & No & No & No & No & Anti-e \\
\hline Results of crossmatch test by adsorbed sera & - & - & - & - & - \\
\hline Compatible RBCs selected for transfusion & $\mathrm{Di}^{\mathrm{a}}-$ & $\mathrm{E}-$ & $c-E-$ & $\mathrm{c}-\mathrm{E}-\mathrm{Jk}^{\mathrm{b}}-\mathrm{Di}^{\mathrm{a}}-$ & $\mathrm{C}-\mathrm{e}^{-}$ \\
\hline Number of times & 2 & 4 & 2 & 2 & 2 \\
\hline Hemolytic episode after RBCs transfusion & No & No & No & No & No \\
\hline $\begin{array}{ll}\text { ALL: acute lymphocytic leukemia } & \text { IAT: indirect } \\
\text { SLE: systemic lupus erythematosus } & \text { DAT: direct }\end{array}$ & $\begin{array}{l}\text { t antiglobu } \\
\text { antiglobuli }\end{array}$ & $\begin{array}{ll}\text { in test } & \text { Alb: } \\
n \text { test } & \text { PEG: }\end{array}$ & $\begin{array}{l}\text { oumin } \\
\text { olyethylene glyc }\end{array}$ & & \\
\hline
\end{tabular}

すなわち $\mathrm{Hb}$ 上昇率 $(\% \mathrm{Hb})$ と定義して評価した．予 測上昇 $\mathrm{Hb}$ 值とは，投与 $\mathrm{Hb}$ 量 $(\mathrm{g})$ を循環血液量 $(\mathrm{d} l)$ で除した值である。また，投与 $\mathrm{Hb}$ 量は赤血球「MAP」 日赤 $400 \mathrm{ml}$ に含まれる平均 $\mathrm{Hb}$ 量 $(58 \mathrm{~g})$ を用いた．輸 血後の溶血の有無は, 輸血前後の LDH（lactate dehydrogenase)值の変動率で評価した。なお，コントロー ル群は濃厚赤血球を 2 単位ずつ各 1 回輸血した際の $\%$ $\mathrm{Hb}$ 抒よび $\mathrm{LDH}$ 值の変動率を評価した。 また，平均值 の差の統計学的検討には $\mathrm{t}$ 検定を用いた.

\section{結果}

\section{1. 不規則抗体検查および DAT}

未処理患者血清（血漿）は，全例で自己対照を含む すべてのパネル血球と反応した。また，パネル血球と の反応に強弱 $(1+\sim 4+)$ を認めたため, 同種抗体の 共存が示唆された (Table 2). 症例 $1 ， 2 ， 3 ， 4$ では $1+$, 症例 5 では $2+$ の自己抗体の反応に加えて, それぞれに 同種抗体様の反応パターンが観察された.

DAT は症例 1 で $3+$, 症例 $2 \sim 4$ で $1+$, 症例 5 で $2+$ であった. 症例 1 の DATは $3+$ と最も強かったが, ZZAP 処理によって除性化した．また，患者血球に結合して いた自己抗体は抗 IgG 血清とのみ反応した。

\section{ZZAP または PEG 吸着上清中の同種抗体}

ZZAP 処理患者血球による吸着上清または未処理患者 血球による PEG 吸着上清を用いて不規則抗体検查を実 施した結果, 各患者からは抗 Rh を主体とする同種抗体
が検出され,うち 3 名からは複数の抗体が同定された. その内訳は, 症例 1 では抗 $\mathrm{Di}^{\mathrm{a}}$, 症例 2 では抗 $\mathrm{E}$, 症例 3 では抗 $\mathrm{c}$, 抗 $\mathrm{E}$, 症例 4 では抗 $\mathrm{c}$, 抗 $\mathrm{E}$, 抗 $\mathrm{Jk}^{\mathrm{b}}$, 抗 $\mathrm{Di}^{\mathrm{a}}$, 症例 5 では抗 C, 抗 e であった (Table 2)。な扔，自己 抗体の力価が同種抗体よりも高く, 自己抗体によって 完全に隠蔽された同種抗体は, 症例 5 の抗 $\mathrm{e}$ のみであっ た.

また，各患者には適合血に同種抗体に対する抗原陰 性血を選択し，交差適合試験で吸着上清との反応が陰 性となった血液を輸血した。

\section{3. 対応抗原陰性赤血球の輸血効果}

自己抗体保有群へ適合血 $(\mathrm{n}=12)$ を輸血した際の $\% \mathrm{Hb}$ は, $89 \pm 20 \%$ (平均 \pm SD) であった (Fig. 1). コント ロール群の\% $\mathrm{Hb}(\mathrm{n}=15,84 \pm 21 \%)$ との間に有意差 （ $\mathrm{p}=0.656 ）$ を認めなかった. 症例 1 で 1 回目の輸血効 果が $43 \%$ と低值を示したが, その時患者には消化管か らの出血があった.

\section{4. 対応抗原陰性赤血球輸血前後の LDH 值の変動}

対応抗原陰性赤血球輸血前後の LDH 值は, 自己抗体 保有群ではそれぞれ $428 \pm 283 \mathrm{IU} / l, 454 \pm 257 \mathrm{IU} / \mathrm{l}$ ( $\mathrm{p}=$ 0.189), コントロール群ではそれぞれ $191 \pm 104 \mathrm{IU} / 1,204 \pm$ $94 \mathrm{IU} / \mathrm{l}(\mathrm{p}=0.100)$ と, 両群とも輸血後にやや上昇した が有意な変動ではなかった(Fig. 2)，また，各群の輸血 前後の LDH 值変動率も自己抗体保有群では $113 \pm 17 \%$, コントロール群では $110 \pm 16 \%$ と両者に差を認めなかっ た $(\mathrm{p}=0.586)$. 症例 1 で輸血効果が $43 \%$ と低値を示し 


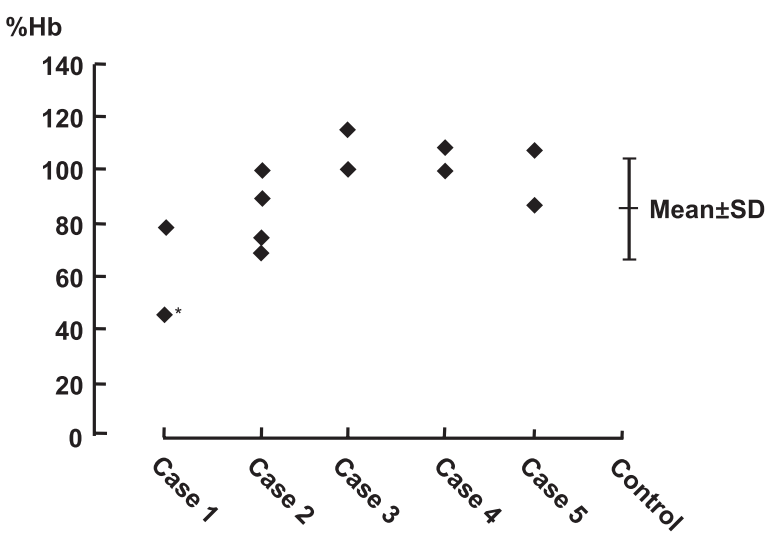

Fig. 1 Rate of hemoglobin increment (\%Hb) after receiving RBCs from donors carrying the corresponding antigen-negative to alloantibodies in 5 patients with autoantibodies.

* With bleeding episode

た時点の LDH 值は, 輸血前後で 467 から $578 \mathrm{IU} / \mathrm{l}$ と $24 \%$ 上昇した。

\section{考察}

自己抗体保有患者が同時に同種抗体を持つ頻度は， 約 12〜 40\% と考えられている ${ }^{8)}$. 我々が遭遇した症例 のうち, 自己抗体によって同種抗体が完全に隠蔽され たのは症例 5 の抗 $\mathrm{e}$ のみであった。一般的には，自己 抗体の力価が比較的低く, かつ同種抗体の力価が自己 抗体よりも高い場合は, 同種抗体の存在や特異性は通 常の不規則抗体スクリーニングでも推定できる. 自己 抗体の力価が高い場合でも，血清を適度に希釈するこ とより, 同種抗体の特異性はパネル血球との反応パター ンから推定できる. しかし, 同種抗体の力価が自己抗 体と同等以下の場合は, 同種抗体の存在は完全に隠蔽 されてしまう. Leger らの検討6)では, 臨床的に重要な 同種抗体が血清希釈 (5 倍希釈)によって推定または同 定できたのは，全体の約 $35 \%$ であり，残りの $65 \%$ は 同種抗体の力価が自己抗体よりも低かったため, ZZAP 処理赤血球を用いた自己抗体吸着法によってのみ検出 されたと述べている．従って，自己抗体保有患者の同 種抗体検出には, 血清希釈法では検出率が低いため, 自己抗体を吸着した上清を用いた検索が不可欠となる.

自己抗体吸着においては, 吸着血球の選択に留意し なければならない，通常，自己抗体の吸着には同種抗 体とは反応しない自己血球を用いるが, 3 力月以内に赤 血球輸血を受けている場合には患者赤血球は使用でき ない.なぜなら，同種抗体産生を誘発した抗原をもつ 同種血球が未だ循環している患者血球を用いると，共 存する同種抗体まで吸着される可能性があるからであ る. Laine らによれば3), 抗 D, 抗 E, 抗 Fy では対応抗

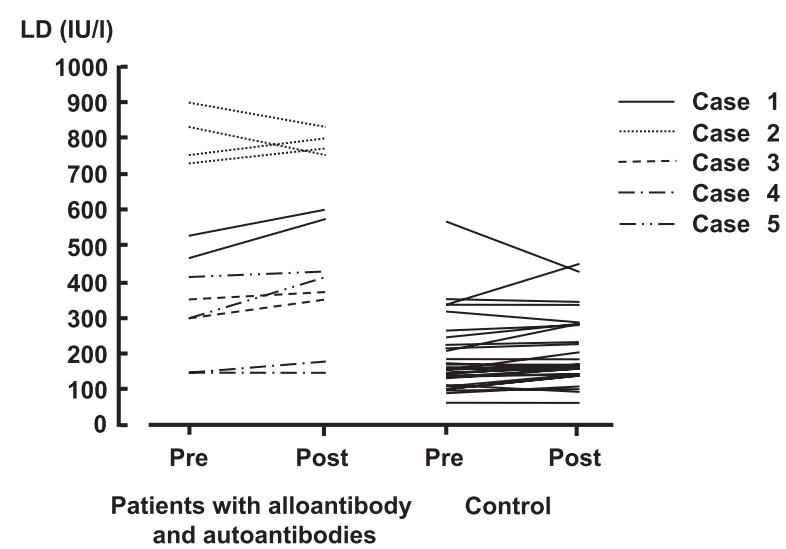

Fig. 2 Levels of lactate dehydrogenase at pre- and posttransfusion in patients with autoantibodies after transfusion of antigen-negative RBCs corresponding to alloantibodies.

原陽性の同種血球が患者血球に 2〜 6\% 混入していると, 各抗体は吸着操作によって完全に吸着除去されるとい う. 同様に, 抗 $\mathrm{Jk}^{\mathrm{a}}$ では 4〜 5\%, 抗 $\mathrm{K}$ では 11〜 17\% の 割合で抗原陽性血球が混入していると, 各抗体は吸着 除去されるという。対象の 5 例には 3 力月以内に輸血 歴が無かったため, 患者血球を用いて自己抗体吸着試 験を実施した。しかし，3 カ月以内に輸血歴がある患者 では Rh と Kidd（日本人では Diego も）抗原が患者と 一致した ZZAP 処理同種血球を吸着血球に選択する ${ }^{4)}$. この際, Kell, Duffy, MNSs 抗原はZZAP 処理によっ て完全に変性されるため, 吸着されずに上清に残った これらの抗体は他の同種抗体と共に検出できる.一方, Rh と Kidd 抗原の一致した同種血球が入手できない場 合は, Rh および Kidd 式血液型があらかじめ夕イピン グされている O 型または同型の ZZAP 処理同種血球 3 種類〔DCCee, DccEE, cceeのいずれかが Jk $(\mathrm{a}+\mathrm{b}-$ ) または Jk $(a-b+)$ )を用いて自己抗体を吸着し, それ ぞれの吸着上清中の同種抗体を検出, 同定する ${ }^{4}$.

患者の輸血前血球の保管は, 患者血球を用いて自己 抗体吸着を実施できるだけでなく，患者赤血球に発現 している主要な同種抗原 (Rh, Kidd, Duffy, Diego, $\mathrm{K}, \mathrm{S}$ 抗原)のタイピングが可能となる. 主要な同種抗 原のフェノタイピングによって, 現在あるいは今後産 生しうる同種抗体特異性の推定が容易となり, 特に同 種抗体を複数保有している患者では適合血の選択にも 有用となる ${ }^{8)}$. 症例 4 は抗 $\mathrm{c}$, 抗 $\mathrm{E}$, 抗 $\mathrm{Jk}^{\mathrm{b}}$, 抗 $\mathrm{Di}^{\mathrm{a}}$ の 4 種の同種抗体を保有していたが，保管した輸血前の患 者血球で主要な同種抗原をタイピングできたことが同 種抗体の同定や適合血選択の一助となった．また，複 数回の輸血が予想される自己抗体保有患者では, 初回 以降の輸血前検査のため自己抗体吸着用として患者血 
球の保管が必要となる，吸着用赤血球は，アルセバー 溶液, $\mathrm{ACD}$ や $\mathrm{CPD}$ などの保存液に浮遊すれば, $4^{\circ} \mathrm{C}$ で 2 力月間は保存可能である ${ }^{910)}$.

DAT が陽性であっても溶血所見がない場合には, 患 者血球から自己抗体を解離して, その特異性を精查す る意義はない ${ }^{1)}$. 自己抗体保有群の 5 名はすべて DAT 陽性 $(1+\sim 3+)$ であったが, 輸血前の検查データか ら自己抗体による溶血所見は認められなかった。そこ で，患者には自己抗体を無視し，同種抗体に適合する 抗原陰性赤血球を輸血した。自己抗体保有群に扔ける 輸血後の \% $\mathrm{Hb}$ (平均 89\%) は, コントロール群 (平均 $84 \%$ ）と有意差を認めなかった. また, 輸血前後の LDH 值の変動からも溶血の所見は認められなかった。この ことから，自己抗体を保有する非 AIHA 患者への赤血 球輸血に際しては，同種抗体に対応する抗原陰性赤血 球を用いることによって，良好な輸血効果が得られる ことが示唆された，症例 1 で, 1 回目の輸血後の $\% \mathrm{Hb}$ が $43 \%$ と低かった. 輸血前後の LDH 值の上昇率は $24 \%$, また総ビリルビン值（T-Bil）の変動は $0.8 \rightarrow 0.9 \mathrm{mg} / \mathrm{d} l$ (デー夕非提示) と軽微であったことから, 輸血効果が 低かった原因は溶血によるものではなく，消化管出血 によるものと考えた．な抢，本症例は輸血後 10 日目に 新たに抗 $\mathrm{E}$ が検出され, 軽度 $(\mathrm{Hb}$ 值 $0.5 \mathrm{~g} / \mathrm{d} l$ 低下, TBil 值 $0.1 \mathrm{mg} / \mathrm{d} l$ 上昇, $\mathrm{LDH}$ 值 $400 \mathrm{IU} / \mathrm{l}$ 上昇）の遅発性 溶血副作用 (DHTR : delayed hemolytic transfusion reacton）を起こした．Shirey ら ${ }^{11} は ， D H T R$ 予防を含む 安全な輸血のため, 自己抗体保有患者へは可能な限り 主要抗原が一致した赤血球の輸血を推奨している.

AIHA 患者では，貧血の進行がなければステロイド による治療効果を待ち, 同種赤血球輸血はできるだけ 回避する。しかし，貧血（ $\mathrm{Hb}: 4 \mathrm{~g} / \mathrm{d} l$ 以下, $\mathrm{Ht}: 12 \%$ 以下）が重篤である AIHA 患者では心不全により死に 至る場合がある，重篤な貧血患者には，低酸素血症を 脱却するのに必要な最低限量の赤血球を輸血する ${ }^{9122}$. しかしながら，重篤な貧血のある AIHA 患者に特異性 （相対的特異性：特定の $\mathrm{Rh}$ 抗原と強く反応する, 例え ば抗 e)をもつ温式自己抗体が検出された場合は, 適合 血の選択に自己抗体の特異性を考慮する必要性につい ては異論があり，未だ一致をみない吕144)。すなわち，特 異性のある温式自己抗体は，体内では対応抗原陰性赤 血球よりも対応抗原陽性赤血球の寿命を短縮すること から，対応抗原陰性の赤血球を輸血すべきとする意見 がある。一方，AIHA 患者は同種免疫応答を起こしや すいため，自己抗体と反応しない抗原（患者が保有し ない抗原）を持つ赤血球を輸血すると，同種抗体を産 生して DHTR を起こすリスクが高まるとする意見があ る.

しかし，自己抗体と同種抗体が共に特異性を有して
いる場合は，自己抗体よりも同種抗体の特異性を優先 し，同種抗体に対応する抗原陰性血を選択する（例え ば，抗 e 自己抗体と抗 $\mathrm{E}$ 同種抗体を保有する患者へは ee 赤血球を輸血). 主要な同種抗原に対する抗体は, 自 己抗体に比べて対応抗原陽性赤血球の寿命をより短縮 すると考えられている ${ }^{13)}$.

\section{結 論}

前感作歴のある自己抗体保有患者への赤血球輸血に 際しては，同種抗体の有無の検索が必須となる。その 際, 自己血球による ZZAP や PEG 吸着法は自己抗体の 除去に有用であった。吸着上清の抗体検査で同種抗体 の共存が認められた 5 名の患者には，適合血として同 種抗体に対応する抗原陰性赤血球を選択して輸血した。 その結果, 全例でコントロール群と同等の $\mathrm{Hb}$ 值上昇が 認められ，また輸血に伴う溶血所見も無かった。この ことから，自己抗体と同種抗体を保有する非 AIHA 患者には，主要な同種抗原を適合した赤血球輸血が有 効であることがわかった.

\section{文献}

1) Morrison PL, Engelfriet CP, Contreras M: Red cell antibodies against self antigens, bound antigens and induced antigens. In: Blood Transfusion in Clinical Medicine, 10th ed, Blackwell, London, 213-240, 1997.

2) Issitt PD, Anstee DJ: Applied Blood Group Serology. $4^{\text {th }}$ ed, Chapter 37: "Warm" antibody-induced hemolytic anemia (WAIHA). Montgomery Scientific Publication, Carolina, 939-993, 1998.

3) Laine EP, Leger RM, Arndt PA, et al: In vitro studies of the impact of transfusion on the detection of alloantibodies after autoadsorption. Transfusion, 40: 1384-1387, 2000.

4) Brecker ME, ed: Technical Manual, $14^{\text {th }}$ ed, Bethesda: American Association of Blood Banks, 2002.

5) Liew YW, Duncan N: Polyethylene glycol in autoadsorption of serum for detection of alloantibodies. Transfusion, 35: 713 (letter), 1995.

6) Legler RM, Garratty G: Evaluation of methods for detecting alloantibodies underlying warm autoantibodies. Transfusion, 39: 11-16, 1999.

7) Ortin JC, Pinaco A, Parra Rafael, et al: Use of polyethylene glycol for performing autologous adsorptions. Transfusion, 45: 694-697, 2005.

8) Petz LD, Garratty G: Immune hemolytic anemias, 2nd ed, Churchill Livingstone, New York, 2004.

9) Branch DR, Petz LD: Detecting alloantibodies in patients with autoantibodies. Transfusion, 39: 6-10, 1999. 
10) Tocci LJ, Reeves CT: Cost saving method for the preparation of differential adsorbing cells (abstract). Transfusion, 38 (suppl): 89, 1998.

11) Shirey RS, Boyd JS, Parwani AV, et al: Prophylactic antigen-matched donor blood for patients with warm autoantibodies: An algorithm for transfusion management. Transfusion, 42: 1434-1441, 2002.

12) Petz LD: Blood Transfusion in acquired hemolytic anemias. In: Petz LD, Swisher SN, Kleinman S, Spence RK, Strauss RG, eds, Clinical Practice of Transfusion Medicine, 3rd ed, Churchill Livingstone, New York, 469-699,
1996.

13) Ness PM: How do I encourage clinicians to transfuse mismatched blood to patients with autoimmune hemolytic anemia in urgent situation? Transfusion, 46: 18591862, 2006.

14) Petz LD: "Least incompatible" units for transfusion in autoimmune hemolytic anemia: Should we eliminate this meaningless term? A commentary for clinicians and transfusion medicine professionals. Transfusion, 43: 1503-1507, 2003.

\title{
RED BLOOD CELL (RBC) TRANSFUSION FOR PATIENTS HAVING ALLOANTI- BODIES AND AUTOANTIBODIES: SELECTION OF APPROPRIATE DONOR BLOOD AND EFFICACY OF ALLOANTIGEN-MATCHED RBCS TRANSFUSION
}

\author{
Hiroyasu Yasuda ${ }^{1)}$, Miho Okutsu ${ }^{1)}$, Kinuyo Kawabata ${ }^{1)}$, Saori Miura ${ }^{1)}$, Chikako Baba ${ }^{1)}$, Satoshi Ono ${ }^{1)}$, \\ Yoko Gunji ${ }^{1)}$, Kazuya Watanabe ${ }^{1)}$, Yuko Obata ${ }^{1)}$, Ryoko Kikuchi ${ }^{2)}$ and Hitoshi Ohto ${ }^{1)}$ \\ ${ }^{1)}$ Division of Transfusion Service and Transplantation Immunology, Fukushima Medical University Hospital \\ ${ }^{2)}$ Shirakawa Kousei General Hospital
}

\begin{abstract}
:
Autoantibodies against red blood cells (RBC) which react with all cells of a screening panel potentially mask the presence of clinically significant alloantibodies, and interfere with pretransfusion antibody screening and compatibility testing.

To remove these autoantibodies, patients' sera were treated using either the ZZAP- or PEG-adsorption methods. Five patients with non-autoimmune hemolytic anemia (non-AIHA) had a single or multiple alloantibodies with the specificities of anti- $\mathrm{Di}^{\mathrm{a}}$, anti-E, anti-c $+\mathrm{E}$, anti-c $+\mathrm{E}+\mathrm{Jk}^{\mathrm{b}}+\mathrm{Di}^{\mathrm{a}}$, and anti-C $+\mathrm{e}$, respectively. These patients received transfusion of antigen-negative RBCs corresponding to the specificity of the alloantibodies which had been detected in the auto-adsorbed sera after removal of the autoantibodies.

The rate (mean, 89\%) of hemoglobin increments in all 5 patients was concordant with that (mean, 84\%) of the control group. Lactate dehydrogenase levels did not increase significantly after transfusion of compatible RBCs.

There findings indicate that autoantibody adsorption procedures are necessary to detect underlying alloantibodies along with autoantibodies. Further transfusion of major alloantigen-matched RBCs is efficient for non-AIHA patients with both allo- and autoantibodies.
\end{abstract}

\section{Keywords:}

autoantibody, alloantibody, adsorption, ZZAP, PEG

(C)2007 The Japan Society of Transfusion Medicine and Cell Therapy

Journal Web Site: http://yuketsu.gr.jp 